\title{
DETERMINATION OF ENERGY CHARACTERISTICS OF CONICAL ROTARY WORKING TOOL FOR TILLAGE
}

\author{
Fanis Yarullin ${ }^{1}$, Ayrat Valiev ${ }^{1}$, Farzutdin Mukhamadyarov ${ }^{2}$, Bulat Ziganshin ${ }^{1}$ \\ ${ }^{1}$ Kazan State Agrarian University, Russia; ${ }^{2}$ Vyatka State Agricultural Academy, Russia \\ fanis4444@mail.ru, ayratvaliev@mail.ru
}

\begin{abstract}
A new rotary working tool, having the shape of a truncated cone for surface tillage, has been developed. A description of the laboratory complex for research is given. An active experiment was conducted, according to a pre-compiled plan. The results of laboratory studies of the energy characteristics of a rotating conical tillage working unit are presented. Two design parameters are independent factors: the angle of attack $\alpha$ and the angle of inclination of the axis of rotation to the horizon $\beta$. The technological parameter is the processing depth $a$. The response functions took the magnitude of the traction force $F$ and the rotation speed of the conical rotary working element $\omega$. The energy characteristics of a rotary tillage tool depend on traction. To ensure minimal traction, it is necessary to choose rational values of $\alpha$ and $\beta$. The rotation speed of the conical rotary working unit affects the quality of the soil treatment. To ensure good quality tillage, it is necessary to select the desired speed of rotation of the working unit. During the experiment, all parameters simultaneously affecting the operation of the conical working unit were changed. The functional dependences of traction resistance and rotation speed of the conical working tool on the angles of attack $\alpha$ and the inclination of the axis of rotation to the horizon $\beta$, as well as on the depth of tillage, are established. A mathematical model of the conical working tool is obtained, which allows calculating the values of traction resistance and rotation speed. The rational values of the installation angles of the working unit $\alpha$ and $\beta$ are substantiated, which ensure minimal traction resistance during operation. The basis of the engineering calculation of the conical working unit is the established patterns. These patterns should be taken into account during the operation of a rotary tillage tool with conical working bodies.
\end{abstract}

Keywords: soil, tillage, rotary tillage tool, conical tillage tool, traction resistance, mathematical model.

\section{Introduction}

Further development of the plant growing sector of the agro-industrial complex is based on the introduction of highly effective high-tech intensive technologies for crop cultivation, which increase the productivity of arable land and ensure environmentally friendly products with minimal material, labor and energy resources. The success of the implementation of these technologies is largely determined by the appropriate level of their technical support. It is known that the key to technology in agriculture is soil cultivation. In the context of the transition to intensive energy-saving crop cultivation technologies, which in most cases involve significant minimization of soil cultivation, tillage machines must provide high-quality surface mulching tillage with minimal energy costs and prepare it for sowing in one pass of the tool [1].

Leading scientists from many countries are engaged in the development and improvement of tillage machines with rotary working tools [2-6]. Having studied the research in this area, we revealed that the use of rotary working tools is a promising direction in the development of new machines for tillage [7-10]. Their main advantage, in comparison with passive working tools, is that they are less energy-intensive. This is achieved by providing the rotating working tools with sliding cutting of the soil layer. We can also highlight the simplicity of design, not many metal consumption and high productivity of rotary working tools of this type. Based on the analysis of existing machine designs and taking into account their shortcomings, we have developed a combined tool for surface mulching tillage with new rotating conical working units $[1 ; 11]$.

The aim of this work is to establish the functional dependence of the traction force and the rotation speed of the conical working tool on the angles of attack and the inclination of rotation axis to the horizon at various values of the depth of tillage, as well as to determine rational values of these angles that provide the minimum traction and maximum rotation speed of the working unit.

\section{Materials and methods}

A rotating conical working tool was made to conduct the experimental studies, as well as to determine the degree of fulfillment of agrotechnical requirements, (Fig. 1a). The working unit consists 
of a rack 1, a hub 2, a ring in the shape of a truncated cone 3 and cutting knives 4 . The experiments were carried out in the soil canal (Fig. 1b) in the Kazan State Agrarian University.

The technological process of rotation of the conical working unit is as follows (Fig. 2). When moving across the field, each rotary working tool 1 penetrates the soil to the depth of processing $a$ and moves at this depth in the direction of unit's movement. In this case, as a result of the influence of friction forces from the side of the treated soil layer 2 on the working surface 3 of each rotary working unit, a torque arises, forcing them to make a rotational movement. This results in sliding cutting of the soil with a cutting edge, which helps reduce the traction resistance of the tool [11].

a)

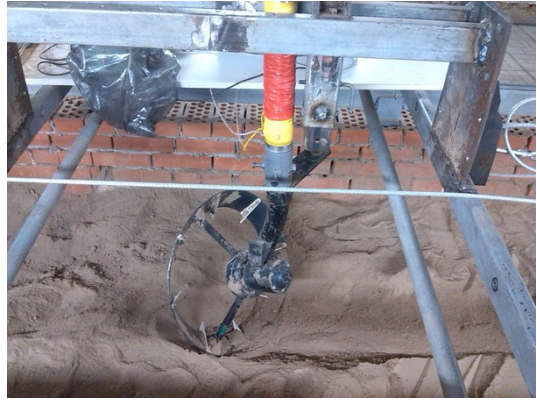

b)

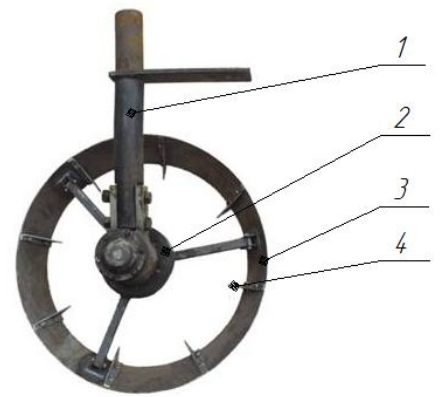

Fig. 1. Rotational conical working tool

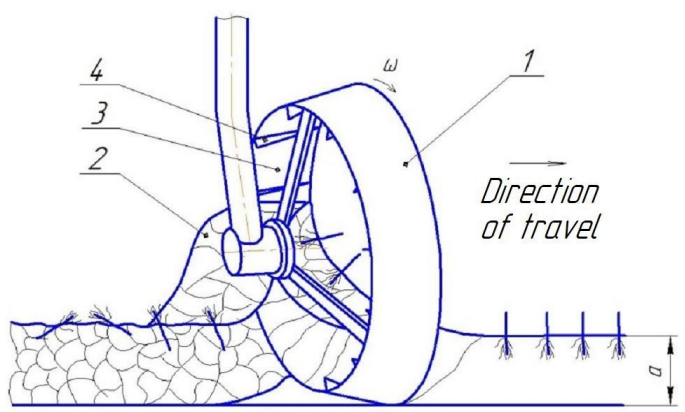

Fig. 2. Technological scheme of rotation of the conical working tool

When the rotary working unit rotates, the soil layer 2 is cut into separate pieces by plate knives 4 , rotating together, it rises to a certain height and turns over when it falls. In this case, part of the crop residues, pests and pathogens of cultivated plants and weed seeds is embedded in the soil to provoke them to germinate for the purpose of their subsequent destruction by chemical means or mechanical treatment.

The implementation of a full-factor experiment matrix is a rather laborious and costly task, in view of the large number of necessary experiments, as well as the need to repeat them for parallel experiments [12-19]. Therefore, it was decided to conduct a fractional factorial experiment. To determine the responses of the system from the action of bending and compression - tension forces, the method of measuring strains using strain gauging was used [20]. The structural diagram of the measuring information system SI-302 (MIS) is presented in Fig. 3.

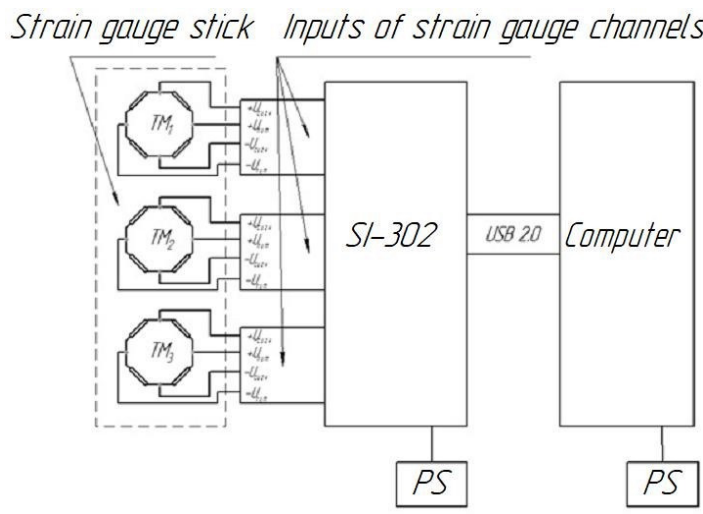

Fig. 3. Block diagram of a measuring information system 
Calibration of strain gauge bridges was carried out jointly with the entire MIS according to the method specified in the MIS SI-302 operating manual [21].

\section{Results and discussion}

An active experiment was conducted in accordance with a pre-compiled plan. In this case, a simultaneous change in all parameters affecting the operation of the conical working tool was provided.

Independent variables (factors) are two design parameters: the angle of attack $\alpha$ and the inclination angle of the rotation axis to the horizon $\beta$, as well as the processing depth $a$, which is a technological parameter. As a response function, the traction force $F$ and the rotation speed of the conical working unit $\omega$ were taken. The amount of energy consumption or the consumption of fuel and lubricants for processing a unit area directly depends on the amount of traction. Therefore, it is necessary to choose rational values of $\alpha$ and $\beta$, providing a minimum of traction. The speed of rotation of the conical working unit affects the quality of tillage. It should be large enough to provide the necessary degree of crumbling. Preliminary studies of the conical working tool established the interdependence between the response functions $F$ and $\omega$. When choosing the values of the angles $\alpha$ and $\beta$, providing an increase in the speed of rotation of the working unit, at the same time, there was an increase in traction. Moreover, this dependence is significantly affected by the depth of tillage.

In connection with the foregoing, the task was to establish the functional dependence of the traction force $F$ and the rotation speed $\omega$ of the conical working unit on the design parameters $\alpha$ and $\beta$ for various values of the processing depth $a$ :

$$
\begin{aligned}
& F=\varphi(\alpha, \beta) ; \\
& \omega=\psi(\alpha, \beta) .
\end{aligned}
$$

Adjusted non-linearity of the desired functional dependencies, the following type of regression equations was chosen.

$$
\begin{aligned}
& F=b_{0}+b_{1} \alpha+b_{2} \beta+b_{12} \alpha \beta+b_{11} \alpha^{2}+b_{22} \beta^{2} ; \\
& \omega=c_{0}+c_{1} \alpha+c_{2} \beta+c_{12} \alpha \beta+c_{11} \alpha^{2}+c_{22} \beta^{2} .
\end{aligned}
$$

To determine the regression coefficients, a full-factor experiment was implemented.

The experiment was implemented at various values of the processing depth $a$. The experimental results are presented in Table 1.

Experimental results at various values of the processing depth $a$

Table 1

\begin{tabular}{|c|c|c|c|c|c|c|c|}
\hline \multirow{2}{*}{$\begin{array}{c}\boldsymbol{\alpha}, \\
\text { degrees }\end{array}$} & \multirow{\beta}{*}{$\begin{array}{c}\boldsymbol{\beta}, \\
\text { degrees }\end{array}$} & $\begin{array}{c}\text { For } \\
\boldsymbol{a}=8 \boldsymbol{c m}\end{array}$ & $\begin{array}{c}\text { For } \\
\boldsymbol{a}=10 \boldsymbol{c m}\end{array}$ & $\begin{array}{c}\text { For } \\
\boldsymbol{a}=12 \boldsymbol{c m}\end{array}$ & $\begin{array}{c}\text { For } \\
\boldsymbol{a}=8 \boldsymbol{c m}\end{array}$ & $\begin{array}{c}\text { For } \\
\boldsymbol{a}=10 \boldsymbol{c m}\end{array}$ & $\begin{array}{c}\text { For } \\
\boldsymbol{a}=12 \boldsymbol{c m}\end{array}$ \\
\hline 20 & 20 & 58.0484 & 82.01323 & 122.7097 & 0.91 & 1.82 & 1.94 \\
\hline 20 & 30 & 38.6502 & 63.30697 & 92.4227 & 1.25 & 1.25 & 2.45 \\
\hline 20 & 40 & 48.12563 & 73.9612 & 96.9138 & 1.59 & 1.82 & 2.39 \\
\hline 35 & 20 & 38.1989 & 63.14 & 85.6603 & 1.19 & 2.87 & 3.76 \\
\hline 35 & 30 & 48.58357 & 74.55627 & 102.6569 & 4.68 & 4.56 & 6.33 \\
\hline 35 & 40 & 41.2107 & 65.26237 & 108.4664 & 2.85 & 1.82 & 3.31 \\
\hline 50 & 20 & 40.8164 & 67.87877 & 103.7784 & 4.66 & 3.88 & 4.45 \\
\hline 50 & 30 & 45.0152 & 58.13863 & 98.333 & 3.53 & 3.42 & 5.02 \\
\hline 50 & 40 & 55.63527 & 82.99787 & 105.829 & 3.19 & 3.88 & 4.11 \\
\hline
\end{tabular}

According to the results of the experiments, the regression equations were constructed for the traction force $F$ and the rotation speed $\omega$, tested for adequacy by the Fisher F-test with a confidence probability of $p=95 \%$. The convergence of the results of theoretical and experimental studies was not less than $90 \%$ with an experimental error of not more than $5 \%$. 
For $a=8 \mathrm{~cm}$ :

$$
\begin{aligned}
& F=140.13-2.602 \alpha-3.55 \beta+0.03 \alpha \beta+0.02 \alpha^{2}+0.04 \beta^{2} ; \\
& \omega=-13+0.46 \alpha+0.45 \beta-0.003 \alpha \beta-0.004 \alpha^{2}-0.005 \beta^{2} .
\end{aligned}
$$

For $a=10 \mathrm{~cm}$ :

$$
\begin{gathered}
F=169.67-2.61 \alpha-3.91 \beta+0.031 \alpha \beta+0.022 \alpha^{2}+0.046 \beta^{2} ; \\
\omega=-4.97+0.32 \alpha+0.129 \beta+0.0004 \alpha \beta-0.0038 \alpha^{2}-0.0024 \beta^{2} .
\end{gathered}
$$

For $a=12 \mathrm{~cm}$ :

$$
\begin{gathered}
F=192.96-2.438 \alpha-3.47 \beta+0.024 \alpha \beta+0.023 \alpha^{2+} 0.04 \beta^{2} ; \\
\omega=-15.25+0.61 \alpha+0.57 \beta-0.0009 \alpha \beta-0.0073 \alpha^{2}-0.0064 \beta^{2} .
\end{gathered}
$$

The obtained regression equations (5-10) are a mathematical model of the conical working tool, which allows us to calculate the technological parameters of the traction force $F$ and rotation speed $\omega$ for given angles $\alpha$ and $\beta$. This makes it possible to choose rational values of the design parameters $\alpha$ and $\beta$.

For a preliminary study of the behavior of the obtained functional dependencies, graphic images were constructed.

Fig. 4 clearly shows the presence of minimum traction. The coordinates of the minimum points can be determined from the conditions that the partial derivatives of the function $\varphi(\alpha, \beta)$ vanish:

$$
\begin{aligned}
& d \varphi(\alpha, \beta) / d \alpha=0 ; \\
& d \varphi(\alpha, \beta) / d \beta=0 .
\end{aligned}
$$

When $a=8 \mathrm{~cm}$, from the regression equation (5) we get:

$$
\begin{gathered}
-2.602+0.04 \alpha+0.03 \beta=0 ; \\
-3.55+0.03 \alpha+0.08 \beta=0 .
\end{gathered}
$$

a)

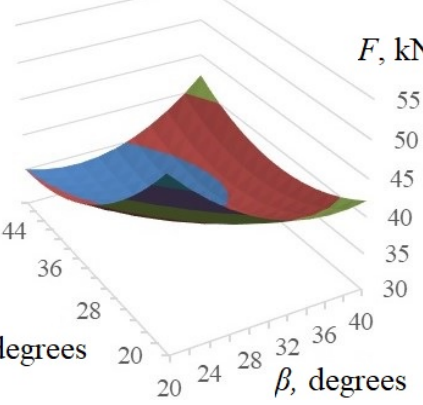

b)

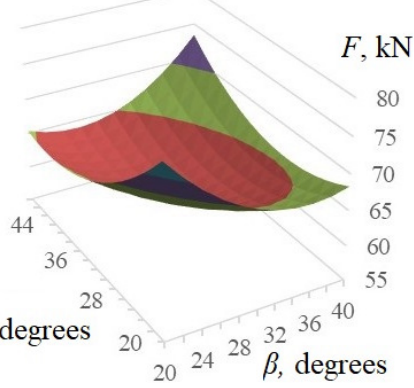

c)

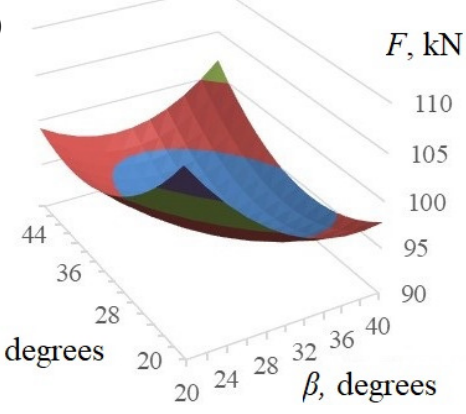

Fig. 4. Dependence of the traction force $F$ on the angles $\alpha$ and $\beta$ for various values of the processing depth $a: \mathrm{a}-a=8 \mathrm{~cm} ; \mathrm{b}-a=10 \mathrm{~cm} ; \mathrm{c}-a=12 \mathrm{~cm}$

The solution to this system gives the following values:

$$
\alpha=44^{\circ} ; \beta=28^{\circ} \text {. }
$$

For $a=10 \mathrm{~cm}$, equation (7) is applied:

$$
\begin{aligned}
& -2.61+0.044 \alpha+0.031 \beta=0 \\
& -3.91+0.031 \alpha+0.092 \beta=0 .
\end{aligned}
$$

Therefore we get:

$$
\alpha=39^{\circ} ; \beta=31^{\circ} \text {. }
$$

For $a=12 \mathrm{~cm}$, we differentiate equation (9):

$$
\begin{gathered}
-2.43+0.046 \alpha+0.024 \beta=0 \\
-3.47+0.024 \alpha+0.08 \beta=0 ;
\end{gathered}
$$


The solution of this system gives:

$$
\alpha=34^{\circ} ; \beta=37^{\circ} .
$$

The nature of the change in the rotational speed at various values of the structural parameters $\alpha$ and $\beta$ is shown in Fig. 5.

As we see, the function $\omega=\psi(\alpha, \beta)$ has a maximum. Moreover, the influence of the angle of attack $\alpha$ on the rotation speed prevails over the influence of the inclination angle of the rotation axis to the horizon $\beta$.

We determine the coordinates of the maximum point using partial derivatives by solving the system of equations:

$$
\begin{aligned}
& d \varphi(\alpha, \beta) / d \alpha=0 \\
& d \varphi(\alpha, \beta) / d \beta=0 .
\end{aligned}
$$

a)

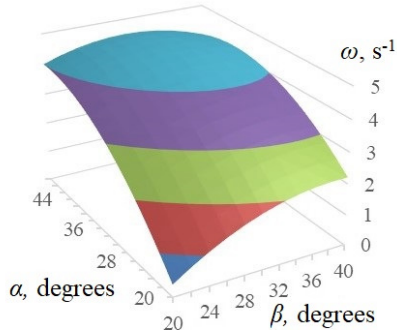

b)

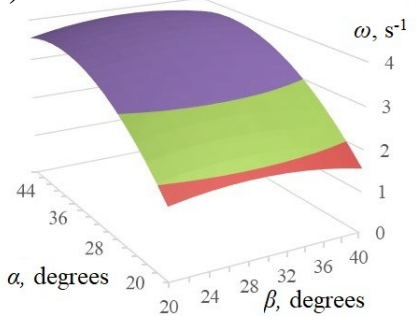

c)

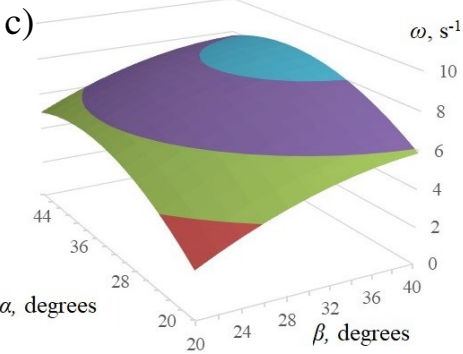

Fig. 5. Dependence of the rotation speed of the conical working unit $\omega$ on the angles $\alpha$ and $\beta$ for various values of the processing depth $a: \mathrm{a}-a=8 \mathrm{~cm} ; \mathrm{b}-a=10 \mathrm{~cm} ; \mathrm{c}-a=12 \mathrm{~cm}$

When $a=8 \mathrm{~cm}$, using equation (6), we obtain:

$$
\begin{gathered}
0.46-0.008 \alpha-0.003 \beta=0 ; \\
0.45-0.003 \alpha-0.01 \beta=0 .
\end{gathered}
$$

The solution of the equations system gives:

$$
\alpha=48^{\circ} ; \beta=25^{\circ} \text {. }
$$

For $a=10 \mathrm{~cm}$, the regression equation (8) is applied:

$$
\begin{gathered}
0.32-0.0076 \alpha+0.0004 \beta=0 ; \\
0.129+0.0004 \alpha-0.0048 \beta=0 ;
\end{gathered}
$$

Therefore we get:

$$
\alpha=44^{\circ} ; \beta=30^{\circ} .
$$

For $a=12 \mathrm{~cm}$, we differentiate equation (9):

$$
\begin{aligned}
& 0.61-0.0146 \alpha-0.0009 \beta=0 ; \\
& 0.57-0.0009 \alpha-0.0168 \beta=0 ;
\end{aligned}
$$

The solution of this system gives the following values:

$$
\alpha=40^{\circ} ; \beta=33^{\circ} \text {. }
$$

Thus, the minimum traction force at a working depth of $8 \mathrm{~cm}$ is provided at the angles $\alpha=44^{\circ}$, $\beta=28^{\circ}$, and coordinates (14) give the maximum rotation speed of the conical working body.

The minimum pulling force at a processing depth of $10 \mathrm{~cm}$ is provided at the angles $\alpha=39^{\circ}$, $\beta=30^{\circ}$, and coordinates (15) correspond to the maximum rotation speed of the conical working tool.

With a processing depth of $12 \mathrm{~cm}$, the minimum traction is provided at the angles $\alpha=34^{\circ}, \beta=37^{\circ}$, and the maximum rotation speed of the conical working unit is achieved at the angles (16).

As we can see, the extreme points of traction and rotation speed do not match. The final values of the desired angles $\alpha$ and $\beta$ can only be selected as a compromise. Sufficiently justified is the choice of 
rational values of the angles in a rectangular region defined by coordinates (11-16), rounded in the direction of increasing the area of the rectangle.

In this case, the desired values of $\alpha$ and $\beta$ must be selected in the region:

$$
\begin{aligned}
& \text { for } a=8 \mathrm{~cm}: 44^{\circ} \leq \alpha \leq 48^{\circ}, 25^{\circ} \leq \beta \leq 28^{\circ} ; \\
& \text { for } a=10 \mathrm{~cm}: 39^{\circ} \leq \alpha \leq 44^{\circ}, 30^{\circ} \leq \beta \leq 31^{\circ} \text {; } \\
& \text { for } a=12 \mathrm{~cm}: 34^{\circ} \leq \alpha \leq 40^{\circ}, 33^{\circ} \leq \beta \leq 37^{\circ} .
\end{aligned}
$$

\section{Conclusions}

1. The results obtained do not qualitatively contradict reality and adequately reflect what is happening. Quantitative estimates depend on the geometry of the conical working unit. In other words, when the taper angle and the radius of the working tool change, the established laws will remain valid, and the specific values of the optimal angles $\alpha$ and $\beta$ will change.

2. The established regularities of the mutual influence of the angles $\alpha$ and $\beta$ on the traction force $\mathrm{F}$ and the rotation speed $\omega$, is the basis of the engineering calculation of the conical working unit. They should also be taken into account when operating a combined cultivator with conical working tools. In particular, therefore, the following can be recommended, when operating a conical working tool. The angle of inclination of the axis of rotation to the horizon $\beta$ and the angle of attack $\alpha$ must be changed depending on the conditions of tillage. During autumn tillage, to reduce the consumption of fuel and lubricants, it is necessary to set the angles $\alpha$ and $\beta$ so with the lowest traction force $\mathrm{F}$.

3. In spring, when preparing the field for sowing, the quality of the soil cultivation, which increases with increasing $\omega$, comes first. Therefore, it is necessary to set the angles $\alpha$ and $\beta$ in such a way as to ensure maximum rotation speed $\omega$.

\section{References}

[1] Валиев А.Р., Яруллин Ф.Ф., Ибятов Р.И., Шириязданов Р.Р. Результаты экспериментальных исследований ротационного конического рабочего органа в почвенном канале (The results of experimental studies of a rotating conical working tool in the soil canal). Bulletin of Kazan State Agrarian University, 2014, vol. 3 (33), pp. 78-85. (In Russian).

[2] Chao Wang, Hongwen Li, Jin He, Qingjie Wang, Caiyun Lu, Xiupei Cheng. Research situation of rotary tillage technology under conservation tillage. International Agricultural Engineering Journal, 2019, No 28(1), pp. 14-20.

[3] Watcharachan S, Prathuang U, Sirisak Ch. Comparative study on soil tillage using rotary tiller and power harrow / International Journal of Agricultural and Biosystems Engineering. vol.11, No. 10, 2017, pp. 725-728.

[4] Ganapathi D., Duraisamy V.M., Shridar B. Development and optimization of rotary blade for tillage equipment / International Journal of Agriculture, Environment and Biotechnology. vol. 11(4), 2018, pp. 673-677.

[5] Khafizov R., Khafizov C., Nurmiev A. etc. Optimization of main parameters of tractor and unit for seeding cereal crops with regards to their impact on crop productivity // Engineering for Rural Development Proceedings. 2018. C. 168-175.

[6] Maksimov I., Adigamov N., Mustafin A. etc. Theoretical fundamentals for determining soil erosion potential. Periódico Tchê Química: órgão de divulgação científica e informativa [recurso eletrônico]. Grupo Tchê Química. Porto Alegre, RS. Brasil, 2019, vol. 16, No 31, pp. 540-557.

[7] Korostylev S., Esaulko A., Ozheredova A, Gromova N, Grechishkina Y. Influence of tillage methods on optimization of nutrition, yield and filling grain of winter wheat on leached chernozem. 18th International Scientific Conference Engineering For Rural Development Proceedings, Volume 18 May 22-24. Latvia University of Life Sciences and Technologies Faculty of Engineering, Jelgava, 2019, pp. 379-385.

[8] Apazhev A., Smelik V., Shekikhachev Y., Hazhmetov L. Combined unit for preparation of soil for sowing grain crops. 18th International Scientific Conference Engineering For Rural Development Proceedings, Volume 18 May 22-24. Latvia University of Life Sciences and Technologies Faculty of Engineering, Jelgava, 2019, pp. 192-198. 
[9] Valiev A., Mukhametshin I., Mukhamadyarov F., Yarullin F., Pikmullin G. Theoretical substantiation of parameters of rotary subsoil loosener. 18th International Scientific Conference Engineering For Rural Development Proceedings, Volume 18 May 22-24. Latvia University of Life Sciences and Technologies Faculty of Engineering, Jelgava, 2019, pp. 312 - 318.

[10] Яруллин Ф.Ф., Ибятов Р.И., Яхин С.М., Гайнутдинов Р.Х. Результаты полевых исследований почвообрабатывающего орудия с эллипсовидными дисками / (The results of field studies of a tillage implement with ellipsoid disks). Bulletin of Kazan State Agrarian University, 2019, vol. 14, No 2 (53), pp. 123-127. (In Russian).

[11]Валиев А.Р., Ибятов Р.И., Яруллин Ф.Ф. Обоснование параметров конического почвообрабатывающего рабочего органа путем решения многокритериальной задачи оптимизации (Justification of the parameters of the conical tillage working tool by solving the multicriteria optimization problem). Achievements of science and technology of the agroindustrial complex, 2017, vol. 7, pp. 69-72. (In Russian).

[12] Ahmadi I.A Power estimator for an integrated active-passive tillage machine using the laws of classical mechanics. Soil \& Tillage Research, 2017, No 171, pp. 1-8.

[13] Alavi, N., Hojati, R. Modeling the soil cutting process in rotary tillers using finite element method. J. Agric. Technol, 2012, No 8 (1), pp. 27-37.

[14] Ani, O.A., Uzoejinwa, B.B., Ezeama, A.O. etc. Overview of soil-machine interaction studies in soil bins. Soil Tillage Res, 2018, No 175, pp. 13-27.

[15] Armin, A., Fotouhi, R., Szyszkowski, W. Experimental and finite element analysis for mechanics of soil-tool interaction. Int. J Mech. Mechatr. Eng, 2017, No 11 (2), pp. 433-439.

[16] Chen, Y., Munkholm, L.J., Nyord, T. A Discrete element model for soil-sweep interaction in three different soils. Soil Tillage Res, 2013, No 126, pp. 34-41.

[17] Mutchler C.K., Carter C.E. Soil erodibility variation during the year. Trans. ASAE, Joseph, Mich., 1983, No 26, 4. pp. 1102-1104.

[18] Johnson R.R. Putting soil movement into perspective. Product. Agr,1988, No 1, 1, pp. 5-12.

[19] Van Liew M.W., Saxton K.E. Dinamic Simulation of Sediment Discharge from Agricaltural Watersheds. Trans. ASEA, 1984, vol. 27, pp. 1087-1093.

[20] Маkаров Р.А., Ренский Л.Б. и др. Тензометрия в машиностроении. Справочное пособие (Strain measurement in mechanical engineering). Reference manual. Mechanical Engineering, 1975. 288 p. (In Russian).

[21]Измерительная информационная система СИ-302. Руководство по эксплуатации. (Measuring information system SI-302. Manual). Kuban: KubNIITiM, 2014. 25 p. (In Russian). 